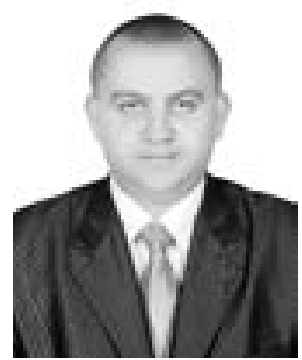

\title{
ПРАВА І СВОБОДИ ЛЮДИНИ ЯК ОСНОВА ЕФЕКТИВНОГО ФУНКЩІОНУВАННЯ ОРГАНІВ ПУБЛІЧНОГО УПРАВЛІННЯ
} доцент кафедри управління та адміністрування Івано-Франківського навчальнонаукового інституту Західноукраїнського національного університету

https://orcid.org/0000-0003-0797-8864

УДК 342.7

DOI 10.32782/NP.2021.1.4

Статья посвящена исследованию особенностей правовой природъ института прав и свобод человека как основы эббекттивного бункиионирования публичного управления. Проанализированъи научныле подходъ отечественных и зарубежных ученъих относительно правовой природъг института прав и свобод человека в контексте современнъхх трансбормационнъих изменений. Обосновано, что низкий уровень экономического развития, нестабильность в социально-политической и правовой сфере, отсутствие эфбеективных фборм правового воспитания граждан обусловили то, что население нашего государства практически не знает своих прав, не умеет их использовать и не требует от окружающих и государства их уважсения и соблюдение. Доказано, что потеницал прав и свобод человека может бътть реализован только тогда, когда для этого существуют необходимъие условия политического, экономического, нравственного, организачионного и иного порядка.

Ключевые слова: государство, права человека, свободъ человека, публичное управление, демократия, юридические гарантии, законодательство.

\section{Постановка проблеми}

Права і свободи людини є невід'ємним і природним наслідком гідності людської особистості, що випливає з самого факту "бути людиною”. Держава, як гарант безпеки, зобов'язана поважати права, свободи та гідність кожної людини та захищати їх дотримання через інтегровану систему захисту прав людини. ліберальна демократія гарантує громадянам низку прав і свобод, а також забезпечує ї безперервність. Поняття прав і свобод людини, знання джерел та сфер їх функціонування $\epsilon$ необхідною умовою вивчення предмету та його ефективності.

У сучасній літературі з цього питання немає однорідності поглядів при визначенні термінології визначень. Динаміка правового захисту процесів реалізації прав людини може спостерігатися як при розширенні каталогу прав людини у міжнародному та національному середовищі, так і при створенні нових методів та інструментів їх дотримання.

Аналіз останніх досліджень і публікацій

Окремі аспекти проблеми було висвітлено у працях С. Алексєєва, В. Бабаєва, В. Венедіктова, Г. Гончарової, Д. Єрмоленко, Р. Кондратьєва, В. Корельського, Л. Аазора, П. Пилипенка, В. Прокопенка, В. Перевалова, О. Процевського, П. Рабіновича, В. Ротаня, В. Селіванова, О. Скакун, В. Тація, Ю. Тодики, Н. Хуторяна, М. Хавронюка та інших.

Теоретичним підгрунтям дослідження також стали праці відомих українських учених, з-поміж яких О. Балинська, Н. Бортник, Т. Гарасимів, І. Жаровська, Р. Ігонін, М. Кельман, В. Ковальчук, I. Аиченко, А. Ауць, В. Макарчук, М. Никифорак, В. Ортинський, О. Остапенко, Б. Стецюк, С. Сливка, А. Суббот, Ю. Тихомиров, Ю. Шемшученко та інші.

Тим не менше, більшість праць вітчизняних і зарубіжних ечених та практиків присвя- 
чено дослідженню переважно конституційно-правових аспектів регулювання інституту прав та свобод людини. У той же час проблема забезпечення прав і свобод людини в контексті реалізації публічного управління є надзвичайно актуальною і зумовила вибір даної теми дослідження.

Метою цього дослідження є формулювання авторських підходів щодо розуміння правової природи прав і свобод людини в контексті розбудови в Україні громадянського суспільства та правової держави.

\section{Виклад основних положень}

Важливим компонентом будь-якої правової системи $е$ інститут прав і свобод людини. Це складне і багатогранне поняття виражає не потенційні, а реальні можливості його власника, закріплені конституцією держави та іншими нормативними актами. 3 огляду на це, питання про єдність прав і свобод людини і громадянина у демократичному суспільстві нині набуває все більшої актуальності в юридичній літературі і підлягає більш широкому дослідженню.

Як наслідок, курс на створення правової держави, на утвердження демократичних принципів управління суспільством немислимий без визнання Україною прав і свобод людини. У силу багатьох причин проблема прав людини в нашій країні, на жаль, не була домінуючою.

Низький рівень економічного розвитку, нестабільність в соціально-політичній і правовій сфері, відсутність ефективних форм правового виховання громадян зумовили те, що населення нашої держави практично не знає своїх прав, не вміє їх використовувати і не вимагає від оточення і держави їх поваги і дотримання.

Права і свободи людини - одне 3 наймолодших понять у словнику політики та суспільства. Однак вони певний час були унікальною соціально-політичною цінністю. Вони стали важливим критерієм оцінки діяльності влади і навіть конституції та законодавчих положень. Права людини виправдовують опозиційні та революційні рухи. Права і свободи людини є програмною метою урядів. Вони $є$ важливим елементом міжнародної політики.
Права і свободи людини - це універсальні моральні права основного характеру, що належать кожній людині в їі контактах $з$ державою. Концепція прав і свобод людини базується на трьох тезах:

* по-перше, вся влада обмежена;

* по-друге, кожна людина має сферу автономії, до якої жоден орган влади не має доступу;

* по-третє, кожна людина може вимагати, щоб держава захищала свої права.

Не існує єдиного визначення прав людини. Енциклопедія міжнародного публічного права, розроблена групою авторів 3 різних країн, визначає права людини як “ці свободи, заходи захисту та переваги, які слід поважати як права, відповідно до сучасних свобод, усі люди повинні мати можливість вимагати від суспільства, у якому вони живуть" [1].

У цьому визначенні основний акцент робився на моральному праві вимагати, щоб суспільство поважало права людини.

Видатний американський конституційний юрист $\lambda$ Лї Хенкін представив кілька додаткових умов прав людини. Науковець вважає, що “це права осіб, які живуть у суспільстві, що зобов’язує товариства виконувати свої вимоги, що випливають із цих прав. Вони універсальні і належать усім людям, що живуть у кожному суспільстві. Вони також мають основний характер, тобто їх не потрібно обгрунтовувати посиланням на будь-які інші права. Проте, це не означає, що права людини є абсолютними; вони можуть бути обмежені, але лише у виняткових випадках, які передбачені заздалегідь та відповідно до визнаних процедур та не на будь-який розсуд" [2].

Права людини належать до категорії моральних законів. Тим не менше вони дещо відрізняються від інших таких законів. Моральний закон може бути приєднаний до окремої людини через його досягнення чи його становище в суспільстві. Навпаки, права людини є універсальними, належать усім людям у будь-яких ситуаціях і незалежно від соціального становища.

Хоча деякі моральні закони можна придбати, права людини є природними, тобто вони належать кожній людині як такій: кожна людина народжується наділеною цими правами. Права людини також не підлягають пе- 


\section{Теорія, історія держави і права, конституційне право}

редачі, що означає, що особи не можуть бути позбавлені цих прав і що людина не може добровільно віддавати ці права державі.

Основна відмінність прав людини від інших загальнолюдських моральних законів - це їх виправдання. Права людини, будучи основними правами, є привілейованою категорією загальнолюдських моральних законів. Їх особливість полягає в тому, що вони не потребують ніякого обгрунтування. Вони належать кожному індивіду як людині, яка є частиною нашого людства.

Досить посилатися на той факт, що істота є людиною, щоб виправдати свої вимоги до прав, що випливають із цих прав. Їх фундаментальна і притаманна природа полягає саме в тому, що вони не потребують обгрунтування; виправдання вимагають відхилення від цих прав.

Однак особливого захисту прав людини немає, оскільки не потрібно мотивувати причини. У разі їх порушення можна посилатися - як у випадку порушення всіх інших моральних законів - на совість, звичаї, почуття справедливості, громадську думку та подібні загальні, але не дуже оперативні поняття.

Для забезпечення кращого захисту прав людини існує тенденція до інституціоналізації ïx у позитивному праві. Однак інституціоналізація сама по собі не може надати деяким правам характер прав людини; вони вже повинні бути основними моральними законами. Позитивний закон не створюе прав людини, він їх підтверджує, максимум. Права людини - це лише ті права, які, незалежно від їх визнання позитивним правом, є невідчужуваними моральними законами базового та універсального характеру.

Загальна декларація прав людини 1948 р. визнала права людини такими моральними правами, які мають усі люди і які повинні мати усі люди. Зусилля, що вживаються до і після їі прийняття, спрямовані на забезпечення механізмів захисту прав як зобов'язальних пактів міжнародного права, так і національного права - призводять до перенесення прав людини із сфери обов'язку в сферу правової реальності, щоб вони були як моральним, так і позитивним законом, щоб вони могли одночасно користуватися владою сили і справедливості.
Здатність відстоювати права є найважливішим аспектом прав людини. Права людини - це не лише високі ідеали чи прагнення, але й удосконалення, що лежать в основі претензій. Аюдина без прав може запитати, клопотати або просити тих, хто має владу над ним.

Перші кроки у визнанні державою прав i свобод людини і громадянина були зроблені Україною в 1990 році, коли була прийнята Декларація про державний суверенітет України, у якій зафіксовано положення про те, що всім громадянам Української PCР гарантуються права і свободи, які передбачені Конституцією Української РСР і нормами міжнародного права, визнаними Українською РСР. У Конституції України 1996 р. закріплено багато положень, що містяться в Европейській конвенції з прав людини та інших міжнародних документах [3;4].

Побудова правової держави передбачає створення такого громадського союзу, який, грунтуючись на праві і законі, встановлює правильні і гуманні взаємини між органами державної влади і особою. Однак у прагненні створити таку державу і визнання міжнародних стандартів до вирішення проблеми забезпечення реалізації громадянами своїх прав i свобод дуже велика дистанція. Невід'ємною складовою такого забезпечення є налагоджений соціально-правовий механізм захисту громадян від порушень їх прав і свобод.

Тим не менше, слід констатувати, що багато із задекларованих у Конституції України фундаментальних прав і свобод потребують співпраці та активної участі держави, у цілому, та органів публічної влади у забезпеченні їх реалізації та дотримання, а саме: до таких слід віднести право на участь в управлінні державними справами, у всеукраїнському та місцевих референдумах, право на справедливий судовий розгляд, право на освіту, працю, охорону здоров'я тощо.

Особливої актуальності це набуває за умов, коли держава в сучасному суспільстві володіє монополією на репрезентацію та захист публічних інтересів, тому що виступає від імені всього суспільства та діє на благо останнього. Однак, будь-яке монопольне становище призводить до свавіляя та різноманітних зловживань, і все це може відбуватися під прикриттям забезпечення пріоритету загальносуспільних 
інтересів, що призводить до звуження, а то й нехтування правами і свободами людини.I саме для того, щоб запобігти такому свавіл^ю, з боку держави має бути встановлений ефективний контроль.

Більше того, права індивіда повинні бути захищені від свавільних дій влади незалежно від того, за згодою чи без згоди громадян ця влада здійснюється. Права і свободи кожної окремої людини одночасно є і виправданням для державної влади, і межами їі виконання. У якості вимог, які людина або громадянин може пред'явити органам держави, ці основні права і свободи, що належать кожному, хто вступає у стосунки 3 державною владою, дозволяють зберегти ці межі. При цьому держава повинна діяти у відповідності до засад верховенства права і справедливості [5, с. 10].

O.В. Чернецька зауважує про те, що “для сучасного стану державно-правової дійсності характерним 6 підготовка нового проєкту Конституції України, то внесення змін до другого розділу Конституції України "Права, свободи та обов'язки людини і громадянина” має базуватися на загальновизнаній системі цінностей та пов'язаних з ними уявлень, поглядів та принципів про місце та роль прав людини в суспільстві та державі [6, с. 89].

Права людини можуть виконувати три функції:

1) захист свободи індивіда від його порушення з боку держави,

2) необхідність створення державою можливості здійснення прав особи,

3) захист прав і свобод індивіда від порушень з боку інших осіб.

Говорячи про першу функцію прав людини, можна загалом сказати, що права людини відіграють роль щита, який повинен захищати людину, а особливо їх свободу, від держави. Суть держави - це влада, незалежно від того, чи це влада для самої влади (правлячої особи чи групи), чи призначена вона для виконання таких завдань, як забезпечення внутрішньої та зовнішньої безпеки держави чи реалізація загального блага чи досягнення інших цілей організованої громади, в державі.

Держава, виконуючи свої завдання, використовує вибрану камеру. Суть його полягає у можливості використання примусу. Навіть ідеальна і найправедніша держава незрівнян- но сильніша за індивіда, зобов'язаного підкорятися державі та закону, який вона видає. Однак примусовою силою можна зловживати. Коли держава виступає арбітром, існує можливість будь-яких рішень, прийнятих їі посадовою особою.

Більше того, державні рішення приймають конкретні люди, які можуть керуватися власними інтересами, люди, яким важко не впливати на власні суб'єктивні судження, забобони та емоції. Вони можуть неправильно використовувати або зловживати своєю владою. Тому виникає необхідність захищати особу від держави та людей, які здійснюють владу від їі імені.

Розглядаючи визначення понять “права” і “свободи”, слід мати на увазі, що ці поняття за час свого існування зазнали значних змін. Серед безлічі різних формулювань найбільш прийнятною може бути інша: право - це система загальнообов'язкових, встановлених у законі норм, принципів і нормативних установок, що виражають міру свободи і відповідальності в суспільстві і які виступають регулятором суспільних відносин.

У широкому сенсі права людини є вихідними і не обмежуються якимось певним колом людей, а поширюються на будь-яку людину, незалежно від того, є він громадянином держави, в якій живе, чи ні. Однак застосування терміна “права людини” в одній зв’язці 3 терміном “права громадянина” тягне за собою змішання цих двох далеко не тотожних понять.

У науковій літературі і на практиці аналогічна тенденція спостерігається і при аналізі застосування термінів “права” і “свободи”. Як правило, вони вживаються в одному контексті, що створює враження їх ідентичності. Розмежування між правами і свободами провести досить важко, оскільки нерідко всю сферу політичних прав з чітко визначеними правомочностями також називають свободою.

Захист особи від небезпеки зловживання владою може мати різні форми. Один 3 них обмеження можливості втручання держави та посадових осіб у певні сфери людського життя. Цьому служать свободи особистості, такі як особиста свобода, свобода совісті та віросповідання, свобода зібрань, свобода асоціацій, свобода пересування та свобода підприємницької діяльності. 


\section{Теорія, історія держави і права, конституційне право}

Свобода - це своєрідний щит, який повинен захищати індивіда від незрівнянно більшої державної влади. Вона захищає автономію особистості і заважають державі втручатися у сферу індивідуальної свободи. Варто додати, що права людини захищають не лише зло, яке влада може завдати людям. Вони також захищають особу від порушень іï автономії з боку влади, яка переслідує їх бачення загальних благ або цілей державної політики.

Потенціал прав і свобод людини може бути реалізований лише тоді, коли для цього існують необхідні умови політичного, економічного, морального, організаційного та іншого порядку. Процес реалізації прав і свобод регулюється особливим механізмом, який включає в себе систему юридичних норм, що гарантують правореалізацію, тобто діяльність владних структур і активна поведінка самого індивіда щодо матеріалізації своїх суб'єктивних прав, спрямованих на досягнення закріплених цими правами благ і соціальних цінностей.

Хоча права людини виникли як інструменти захисту від свавілля недемократичних сил, вони так само необхідні як у демократичній системі, так і в самодержавній.

Ще з часів судового процесу над Сократом добре відомо, наскільки лицемірна та нечутлива демократія може ставитися до меншин та дисидентів. Хоча демократія визначає спосіб прийняття соціальних рішень, права людини встановлюють обмеження для рішень, прийнятих усіма органами влади, включаючи демократичну владу.

\section{Висновок}

Таким чином, законодавство не може задовольнити всіх запитів громадян і врахувати різноманіття явищ суспільного життя, які впливають на ефективність реалізації ними своїх суб'єктивних прав. Більше того, навіть регламентовані правові норми не завжди реалізовуються в повному обсязі внаслідок ослаблення системи гарантій, зловживань 3 боку посадових осіб, інших непрогнозованих витрат, тобто маються на увазі такі негативні явища, як бюрократичне свавіляя, некомпетентність чиновників, міжнаціональні конфлікти, безсилля влади, порушення законності тощо.

\section{Мiтература}

1. Encyclopedia of Public International Law. Volume 8: Human Rights and the Individual in International Law. International Economic Relations. Published under the auspices of the Max Planck Institute for Comparative Public Law and International Law, under the direction of Rudolf Bernhardt. Amsterdam: North Holland Publishing Company, 1985. 551 pp.

2. The Age of Rights. By Louis Henkin. New York: Columbia University Press, 1990. 220 p.

3. Декларація про державний суверенітет України: Декларація від 16.07.1990 № 55XII // База даних “Законодавство України” / Верховна Рада України. URL: https://zakon. rada.gov.ua/laws/show/55-12 .

4. Конституція України: Закон України від 28.06.1996 № 254 к/96-ВР // База даних “Законодавство України” / Верховна Рада України. URL: http://zakon3.rada.gov.ua/laws/ show $/ 254 \%$ D0\%BA/96\%D0\%B2\%D1\%80/page

5. Конституційна держава та права людини й основоположні свободи: Україна та європейський досвід: колект. монографіяО. М. Ващук та ін.; Закарпат. держ. ун-т. Ужгород: Мистецька лінія, 2008. 347 с.

6. Чернецька О.В. Права та свободи людини і громадянина як основа функціонування органів публічної влади. Часопис Київського університету права. № 1. 2014. С. 87-90.

\section{References:}

1. Encyclopedia of Public International Law . Volume 8: Human Rights and the Individual in International Law. International Economic Relations. Published under the auspices of the Max Planck Institute for Comparative Public Law and International Law, under the direction of Rudolf Bernhardt. Amsterdam: North Holland Publishing Company, 1985. 551 pp.

2. The Age of Rights. By Louis Henkin. New York: Columbia University Press, 1990. 220 p.

3. Deklaratsiia pro derzhavnyi suverenitet Ukrainy: Deklaratsiia vid 16.07.1990 № 55XII // Baza danykh "Zakonodavstvo Ukrainy" / Verkhovna Rada Ukrainy. URL: https://zakon. rada.gov.ua/laws/show/55-12

4. Konstytutsiia Ukrainy: Zakon Ukrainy vid 28.06.1996 № 254 k/96-VR // Baza danykh 


\section{АНОТАЦІЯ}

Стаття присвячена дослідженню особливостей правової природи інституту прав і свобод людини як основи ефективного функціонування публічного управління. Проаналізовано наукові підходи вітчизняних та зарубіжних учених щодо правової природи інституту прав і свобод людини в контексті сучасних трансбормачійних змін. Обгрунтовано, що низъкий рівенъ економічного розвитку, нестабільність у соиіально-політичній і правовій сбері, відсутність ефективних борм правового виховання громадян зумовили те, що населення нашої держави практично не знає своїх прав, не вміє їх використовувати $i$ не вимагає від оточення $i$ держави їх поваги $i$ дотримання. Доведено, що потенціал прав $i$ свобод людини може бути реалізований лише тоді, коли для изього існують необхідні умови політичного, економічного, морального, організаиійного та іншого порядку.

Ключові слова: держава, права людини, свободи людини, публічне управління, демократія, юридичні гарантії, законодавство.

"Zakonodavstvo Ukrainy" / Verkhovna Rada Ukrainy. URL: http://zakon3.rada.gov.ua/laws/ show/254\%D0\%BA/96\%D0\%B2\%D1\%80/page

5. Konstytutsiina derzhava ta prava liudyny y osnovopolozhni svobody: Ukraina ta yevropeiskyi dosvid: kolekt. Monohrafiia. O. M. Vashchuk ta in.; Zakarpat. derzh. un-t. Uzhhorod: Mystetska liniia, 2008. 347 s.

6. Chernetska O.V. Prava ta svobody liudyny i hromadianyna yak osnova funktsionuvannia orhaniv publichnoi vlady. Chasopys Kyivskoho universytetu prava. № 1. 2014. S. 87-90.

\section{Zagurskyy O.B. HUMAN RIGHTS AND FREEDOMS AS A BASIS FOR THE EFFECTIVE FUNCTIONING OF PUBLIC ADMINISTRATION}

The article is devoted to the study of the peculiarities of the legal nature of the institute of human rights and freedoms as a basis for the effective functioning of public administration. The scientific approaches of domestic and foreign scientists to the legal nature of the institute of human rights and freedoms in the context of modern transformational changes are analyzed. The author studies the phenomenon of the institute of human rights and freedoms, and also formulates the author's approaches to the peculiarities of improving effective mechanisms for their provision and implementation in the context of further implementation of Ukraine's state policy in the field of human rights.

It is substantiated that the low level of economic development, instability in the sociopolitical and legal sphere, lack of effective forms of legal education of citizens have led to the fact that the population of our state does not know their rights, does not know how to use them and does not demand respect from others compliance. It is proved that the potential of human rights and freedoms can be realized only when there are the necessary conditions for political, economic, moral, organizational and other order.

It is specified that human rights are only those rights which, regardless of their recognition as a positive right, are inalienable moral laws of basic and universal character.

It has been established that any monopoly position in the field of human rights leads to arbitrariness and various abuses, and all this can take place under the guise of ensuring the priority of public interests, which leads to a narrowing or even neglect of human rights and freedoms.

Based on the study, it was concluded that the process of realization of rights and freedoms is governed by a special mechanism that includes a system of legal norms that guarantee law enforcement, ie the activities of government agencies and the active behavior of the individual to materialize their subjective rights. achievement of the benefits and social values enshrined in these rights.

In addition, regulated legal norms are not always fully implemented due to the weakening of the system of guarantees, abuse by officials, and other unforeseen expenses, ie such negative phenomena as bureaucratic arbitrariness, incompetence of officials, interethnic conflicts, powerlessness of power, powerlessness of power are meant. legality.

Key words: state, human rights, human freedoms, public administration, democracy, legal guarantees, legislation. 